\title{
Assessment of lodine in Salt Samples from North Delhi Schools
}

\author{
Anshu Sharma', KL Ramesh ${ }^{2}$, Rinku Sharma $^{3}$, Navin Verma $^{4}$, Robin Marwal ${ }^{5}$, \\ Atindra Kumar Pandey ${ }^{6}$, Radhakrishnan VS \\ ${ }^{1}$ Additional Director and Head, Biochemistry \& Non-Communicable Diseases (NCD) Division. \\ ${ }^{2}$ Advisor, Biochemistry Division, ${ }^{3}$ Deputy Director, NCD Division, ${ }^{4}$ Assistant Director, NCD Division, ${ }^{5,6,7}$ Assistant Director, \\ Biochemistry Division, National Center for Disease Control (NCDC), Delhi, India.
}

DOI: https://doi.org/10.24321/0019.5138.202030

\section{I $\quad \mathbf{N} \quad \mathbf{F} \quad \mathbf{O}$}

\section{Corresponding Author:}

Navin Verma, NCD Division, National Center for Disease Control (NCDC), Delhi, India.

E-mail Id:

drnavinverma@rediffmail.com

Orcid Id:

https://orcid.org/0000-0002-8356-1318

How to cite this article:

Sharma A, Ramesh KL, Sharma R, Verma N, Marwal R, Pandey AK. Assessment of lodine in Salt Samples from North Delhi Schools. J Commun Dis 2020; 52(3): 49-52.

Date of Submission: 2020-03-12

Date of Acceptance: 2020-05-18

\section{$\begin{array}{llllllll}\mathbf{A} & \mathbf{B} & \mathbf{S} & \mathbf{T} & \mathbf{R} & \mathbf{A} & \mathbf{C} & \mathbf{T}\end{array}$}

lodine is an essential micronutrient required for normal thyroid function, growth, and development. lodine deficiency can lead to a variety of health and developmental consequences known as lodine Deficiency Disorders (IDDs). Realizing the magnitude of the problem and to ensure its prevention by $100 \%$ consumption of adequately iodized salt ( $\geq 15 \mathrm{ppm})$, National lodine Deficiency Disorders Control Programme (NIDDCP) is being implemented in India. However, periodic assessment of the salt used is needed to ensure the same. Hence, with the objective of assessment of iodine, household salt samples were collected from students of four schools in North Delhi in October 2019. Awareness programme was also planned among the school children in view of Global lodine Deficiency Disorders Prevention Day. The iodine content of the salt was estimated by standard iodometric titration method. 10 $(10.4 \%)$ salt samples were found to have iodine content $<15 \mathrm{ppm}$. Reasons for low iodine content in the 10 samples need to be assessed along with the information regarding the type of salt used. Measures need to be taken to ensure $100 \%$ consumption of adequately iodized salt ( $\geq 15 \mathrm{ppm}$ ). Also, such periodic assessment should be undertaken to find out the situation in different schools.

Keywords: IDDs, lodized Salt, Delhi

\section{Introduction}

lodine is an essential micronutrient required for normal thyroid function, growth and development. Iodine deficiency can lead to a variety of health and developmental consequences known as IDDs. lodine deficiency is a major cause of preventable mental retardation. Iodine deficiency is especially damaging during pregnancy and in early childhood. In their most severe forms, IDDs can lead to cretinism, stillbirth and miscarriage; even mild deficiency can cause a significant loss of learning ability. ${ }^{1}$

\section{Magnitude of IDDs}

IDDs are a worldwide major public health problem. More than 1.5 billion people all over the world are at risk of IDD. In India, it is estimated that more than $\mathbf{2 0 0}$ million people are at risk of IDDs and 71 million persons are suffering from goitre and other IDDs. However, all these disorders can be 
easily prevented before they occur. The simplest method to prevent the broad spectrum of IDD is to consume iodized salt daily. ${ }^{1}$

Realizing the magnitude of the problem the Government of India launched a 100 per cent centrally assisted National Goitre Control Programme (NGCP) in 1962. In August, 1992 the NGCP was renamed as National lodine Deficiency Disorders Control Programme (NIDDCP) with the inclusion of wide spectrum of IDDs. The programme is being implemented in all the states/ UTs for entire population. ${ }^{1}$

\section{Goal of NIDDCP}

- To bring the prevalence of IDD to below $5 \%$ in the country.

- To ensure $100 \%$ consumption of adequately iodized salt (15 ppm) at the household level.

To ensure the use of iodized salt, the Government of India has issued the notification banning the sale of non-iodized salt for direct human consumption in the country with effect from May, 2006 under the Prevention of Food Adulteration Act $1954 .{ }^{1}$ Periodic assessment of the salt used is needed to ensure the same. With this background, the following study was planned in four schools in North Delhi. Children of class $6 \& 7$ were chosen as they form part of the age group of 6-12 years which is physiologically vulnerable for IDDs and is easily accessible. ${ }^{2}$

\section{Objectives}

- Assessment of iodine in salt samples collected from students of four schools in North Delhi.

- Create awareness among school children regarding prevention of IDDs.

\section{Methods of Salt lodine Testing}

The overall study duration was 1 month (October 2019). Permission was taken from the Directorate of Education: School Branch, Government of National Capital Territory of Delhi for conducting the activity in view of Global lodine Deficiency Disorders Prevention Day which is observed every year on $21^{\text {st }}$ October to raise awareness of iodine deficiency and its devastating effects on brain development. Four government schools were identified in North Delhi in close proximity to the institution/laboratory where the study was planned. For convenience and better coordination, those schools were selected, which were in close proximity to the parent organization NCDC, Delhi. 25 children of class $6 / 7$ from each school were asked to get around 5 tablespoons of household salt sample each in air tight polythene bag for iodine testing. They were also asked to mention their name and locality with the sample for identification.

\section{Method of Creating Awareness}

Awareness programme among children of class $6 / 7$ of the same four schools was also planned. Awareness activity was conducted in the four schools one after the other over a period of 2 weeks according to the time slot given by the school. Awareness was brought about by imparting health education, distribution of IEC material related to IDDs, demonstration of rapid salt iodine testing kit and conducting poster making competition for the school children of class $6 / 7$.

\section{Statistical Analysis}

The results of salt iodine testing were entered in MS Excel and analysis was done using the same over a period of 1 week including the graph \& chart preparation.

\section{Result}

A total of 96 salt samples were collected and tested at NCDC within a period of one week. The remaining samples were of insufficient quantity. The iodine content of the salt was estimated by field test kit as well as standard iodometric titration method. ${ }^{3,4,5}$

Table I.Results of iodine in salt samples according to field test kit

\begin{tabular}{|c|c|}
\hline lodine content (in ppm) & No. of salt samples $(\mathbf{n}=\mathbf{9 6})$ \\
\hline 0 & Nil \\
\hline 5 & 4 \\
\hline 15 & 13 \\
\hline Above 30 & 79 \\
\hline
\end{tabular}

As shown in Table 1, according to the field test kit, iodine content was 5 ppm in four salt samples, 15 ppm in 13 salt samples and above 30ppm in 79 salt samples.

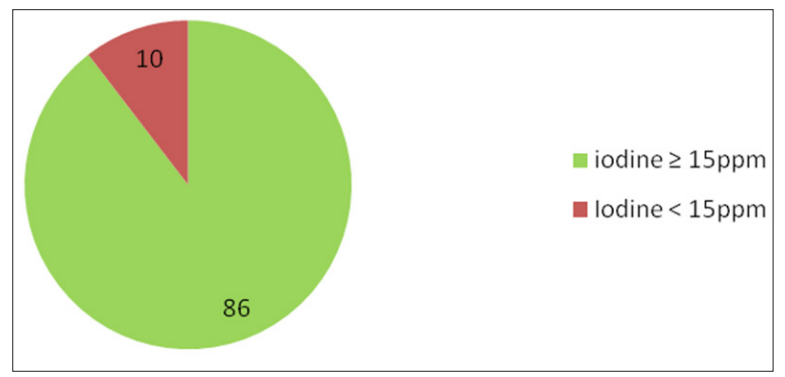

Figure I.lodine values of 96 sale samples

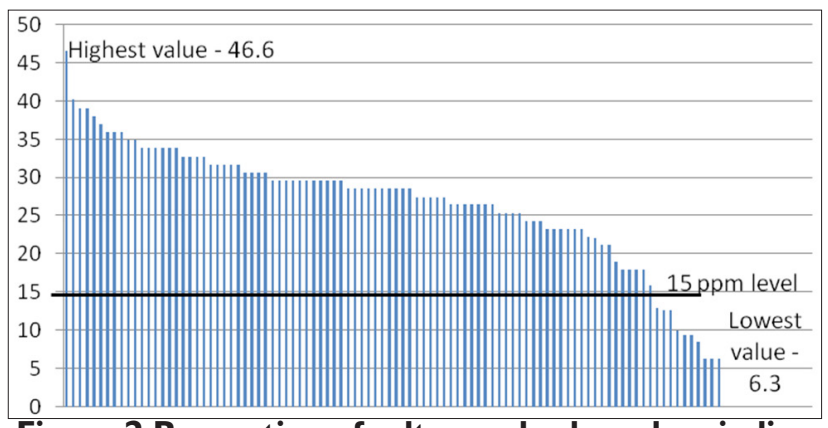

Figure 2.Proportion of salt samples based on iodine content $(n=96)$ 
As shown in Figure 1, according to the standard iodometric titration method, the salt iodine levels ranged from 6.3 ppm to $46.6 \mathrm{ppm}$. Out of the total 96 salt samples, 86 $(89.6 \%)$ samples were found to have iodine $\geq 15 \mathrm{ppm}$ as shown in Figure 2. The remaining 10 (10.4\%) samples had iodine $<15 \mathrm{ppm}$.

A total of 257 students participated in the competition and five prizes were given in each of the four schools.

Altogether 705 students of class 6 / 7 and 30 teachers were made aware about various aspects of IDDs.

\section{Topics Covered in Awareness Programme}

- Basic information about iodine, it's functions, sources and daily requirement in diet.

- IDDs and prevention of iodine deficiency by use of iodized salt.

\section{Discussion}

According to a study in the year $2012,87 \%$ of salt samples collected from Delhi school children had stipulated level of iodine of $15 \mathrm{ppm}$ and more. ${ }^{6}$ Another study among a slum population of North-East Delhi in the year 2008 had shown that $75.6 \%$ households were consuming adequately iodized salt ( $\geq 15 \mathrm{ppm}$ iodine). ${ }^{7}$ A multi-center study of household salt from high school students of four centers in India, published in 2011, had shown that the proportion of samples with iodine content $>15$ ppm was $48.4 \%$ in Jodhpur, $80.2 \%$ in Vadodara, $91.5 \%$ in Delhi and $98.8 \%$ in Dibrugarh. ${ }^{8}$ district, Uttar Pradesh, published in 2014, it was found that around $96 \%$ of household salt samples were having iodine content $\geq 15$ ppm. ${ }^{10}$ Regarding school children of Kangra district, Himachal Pradesh, a study done in the year 2012 showed that $82.3 \%$ of families of the school children were consuming salt with iodine content $\geq 15$ ppm. ${ }^{11}$

In a recent study from Begusarai district of Bihar, published in 2019, $79 \%$ household salt samples were found to be adequately iodized (>15 ppm iodine)..$^{12}$ In another study in BellurHobli in Mandya district, Karnataka, in the year 200506 estimation of iodine content of salt samples revealed that $90.75 \%$ school children consumed adequately iodized salt (>15ppm). ${ }^{13}$

Findings of National family health survey-4 (NFHS, 201516) show that $93 \%$ of households are using iodized salt as compare to $73 \%$ in NFHS-3(2005-06). ${ }^{1}$

\section{Conclusion}

Despite widespread availability of iodized salt and attempts to spread awareness regarding consumption of iodized salt, this study found that $89.6 \%$ salt samples had iodine content $\geq 15$ ppm and remaining $10.4 \%$ had iodine content $<15$ ppm. Reasons for low iodine content in the ten samples need to be assessed along with the information regarding the type of salt used. Probable reasons may be at the production/ manufacturing level or loss of iodine during improper transportation/ storage, exposure to sunlight, high temperature or humidity, long duration of storage, impurities, etc.

Table 2.Results of other similar studies in past regarding iodine in sale samples

\begin{tabular}{|c|c|c|c|}
\hline Year & Site & Subjects & Samples with iodine $\geq 15$ ppm \\
\hline $2005-6^{13}$ & Mandya & School children & $90.75 \%$ \\
\hline $2005-6^{1}$ & NFHS & Household samples & $73 \%$ \\
\hline $2008^{7}$ & N-E Delhi & Slum population & $75.6 \%$ \\
\hline $2011^{8}$ & $\begin{array}{c}\text { Jodhpur, Vadodara, Delhi and } \\
\text { Dibrugarh }\end{array}$ & High school students & $\begin{array}{c}48.4 \%, 80.2 \%, 91.5 \% \text { and } 98.8 \%, \\
\text { respectively }\end{array}$ \\
\hline $2012^{6}$ & Delhi & School children & $87 \%$ \\
\hline $2012^{11}$ & Kangra & School children & A2.3\% \\
\hline $2014^{10}$ & Meerut - Urban & Household samples & More than $90 \%$ \\
\hline $2015^{9}$ & North India & Pregnant women & $93 \%$ \\
\hline $2015-16^{1}$ & NFHS & Household samples & $79 \%$ \\
\hline $2019^{12}$ & Begusarai & Household samples & \\
\hline
\end{tabular}

As seen in Table 2, other similar studies done in the past in areas of Delhi and other states have shown different results.

In a study in the year 2015, about status of iodine nutrition from Northern India, it was observed that more than 90 $\%$ of pregnant women were using adequately iodized salt ( $\geq 15 \mathrm{ppm}$ iodine). ${ }^{9}$ In another study in urban area of Meerut

\section{Recommendation}

Measures need to be taken to ensure $100 \%$ consumption of adequately iodized salt ( $\geq 15 \mathrm{ppm}$ ). Also, such periodic assessment should be undertaken to find out the situation in schools in different geographical areas along with the added benefit of increasing awareness among school children. 


\section{Acknowledgement}

Special thanks to Dr. Sujeet Kumar Singh, Director, NCDC for permitting this activity. We are also thankful to Assistant Directors, Dr. Manoj Kumar Singh, Sh. Suman Shekhar, Assistant Research Officer, Mr. Rajendra Singh Rautela, Technitian, Mr. A. Anbarasan and Laboratory Assistant, Mr. Lalit Kumar Tyagi for their support.

\section{Ethic Approval}

No biological samples were collected from any individual. Only household salt samples were collected. No personal identifiable information was included in the study. Permission was taken from the Directorate of Education: School Branch, Government of National Capital Territory of Delhi. Also, approval was taken from the Director, NCDC Delhi

\section{Source of Financial Support: NCDC, Delhi \\ Conflict of Interest: None}

\section{References}

1. National Health Portal, Ministry of Health and Family Welfare, Government of India. Available from: https:// www.nhp.gov.in/global-iodine-deficiency-disordersprevention-day_pg.

2. WHO/UNICEF/ICCIDD. Indicators for assessing iodine deficiency disorders and their control through salt iodization. World Health Organization, Geneva. 1994.

3. Dunn JT, Crutchfield HE, Gutekunst R et al. Methods for measuring iodine in urine. A Joint Publication of WHO/UNICEF/ICCIDD 1993; 18-23.

4. Karmarkar MG, Pandav CS, Krishnamachari KAVR. Principle and procedure for iodine estimation-a laboratory manual. Indian Council of Medical Research, New Delhi, India.1986; 1-17.

5. Revised Policy Guidelines on National Iodine Deficiency Disorders Control Programme. Revised Edition. IDD and Nutrition Cell, Directorate General of Health Services, Ministry of Health and Family Welfare, Government of India, New Delhi. 2006; 21-24.

6. Kapil U, Sareen N, Bhadoria AS. Status of iodine deficiency among children in National Capital Territory of Delhi - a cross-sectional study. Journal of Tropical Pediatrics 2013; 59(4): 331-332.

7. Agarwal S, Sethi V, Sharma D et al. Consumption of iodized salt among slum households of North-East Delhi, India. Indian J Community Med 2009; 34(4): 368-369.

8. Singh MB, Sharma SK, Nair S et al. Status of iodine content of salt in four regions of India. Indian J Pediatr 2011; 78(6): 684-687.

9. Kant S, Haldar P, Lohiya A et al. Status of iodine nutrition among pregnant women attending antenatal clinic of a secondary care hospital: A cross-sectional study from Northern India. Indian J Community Med 2017; 42: 226-229.

10. Gupta A, Sharma D, Deshpande AV et al. Monitoring and estimation of iodine content of edible salt in urban areas of Meerut district, after four decades of Universal Salt lodization. International Journal of Biomedical and Advance Research 2014; 5(2): 93-95.

11. Kapil U, Pandey RM, Kabra M et al. Status of iodine deficiency in district Kangra, Himachal Pradesh after 60 years of salt iodization. European Journal of Clinical Nutrition 2013; 67: 827-828.

12. Kumar P, Agrawal N, Ranjan A et al. A study on estimate of iodine deficiency disorders and adequacy of iodized salt consumption in Begusarai district of Bihar, India. Indian J Comm Health 2019; 31(1): 16-23.

13. Sridhar PV, Kamala CS. lodine status and prevalence of goiter in school going children in rural area. Journal of Clinical and Diagnostic Research 2014; 8(8): PC15-7. 